\title{
Estimation of reference evapotranspiration for Parbhani district
}

\section{TARATE SURYAKANT BAJIRAO AND HARISH W. AWARI}

Received : 19.07.2016; Revised : 15.02.2017; Accepted : 01.03.2017

See end of the Paper for authors' affiliation

Correspondence to :

TARATE

SURYAKANT BAJIRAO

Department of Soil and Water Conservation Engineering, College of Technology, G.B. Pant University of Agriculture and Technology, Pantnagar, U.S. NAGAR (UTTARAKHAND) INDIA

Email : taratesuryakant01@

gmail.com
- ABSTRACT : Estimation of reference evapotranspiration (ET $)_{\mathrm{o}}$ is essential for planning the irrigation water use in arid and semiarid region. Estimation of reference evapotranspiration $\left(\mathrm{ET}_{\mathrm{o}}\right)$ is an important part of agricultural water management in local and regional water balance studies. At the field scale, estimation of reference evapotranspiration $\left(\mathrm{ET}_{\mathrm{o}}\right)$ is important in irrigation planning and scheduling and is an integral part of field management decision support tools. This study focuses on estimating the reference evapotranspiration (ETo) using 32 years meteorological data by CROPWAT software. The FAO-56 Penman-Monteith method has been recommended as the standard method for estimating reference evapotranspiration $\left(\mathrm{ET}_{0}\right)$ was used.

- KEY WORDS : Evapotranspiration, CROPWAT, Agricultural water management

- HOW TO CITE THIS PAPER : Bajirao, Tarate Suryakant and Awari, Harish W. (2017). Estimation of reference evapotranspiration for Parbhani district. Internat. J. Agric. Engg., 10(1) : 51-54, DOI: 10.15740/ HAS/IJAE/10.1/51-54. 